\title{
QUALITY OF GROUNDWATER IN WESTERN THESSALY THE PROBLEM OF NITRATE POLLUTION
}

\section{DIMOPOULOS \\ M. CHALKIADAKI \\ M. DASSENAKIS* \\ M. SCOULLOS}

\author{
University of Athens, Department of Chemistry, Section III \\ Laboratory of Environmental Chemistry \\ Panepistimiopolis Athens, 15771, Athens
}

Selected from papers presented at the $8^{\text {th }}$ Conference on Environmental Science and Technology, 8 - 10 September 2003, Lemnos, Greece. *to whom all correspondence should be addressed:

Tel/fax: +(30)-210 7274269 e-mail: edasenak@cc.uoa.gr

\section{ABSTRACT}

The results of a research study about the groundwater quality in western Thessaly, that took place during the period 2001-2002, are presented in this paper. The study included two samplings during May and August of 2002. In May the water table is at high level while at the end of the summer the level of the water table is as low as it can be. Fourteen sampling stations were selected and the samples were received from deep wells. In addition to nitrogen compounds, several other chemical parameters were measured. UV-Vis Spectrometry, Atomic Absorption Spectrometry and Emission Spectrometry were used for the chemical analyses.

The groundwater of region Farsala has been found to contain very high nitrate concentrations and also high concentrations of calcium, nitrite and bicarbonates. The increased nitrate level in groundwater is a major problem, caused by the fertilizers that are used in most areas with intensive agriculture like Thessaly. The concentrations of heavy metals were very low. The ionic ratios of major cations indicate that the groundwater originates mostly from calcareous aquifers and there is a constant water flow.

The classification according to conductivity, chloride concentration and degree of alkalinity characterizes the groundwater as water of medium quality that can be used for irrigation at soils with good conditions of leaching.

KEYWORDS: groundwater, nitrogen compounds, fertilizers, Thessaly

\section{INTRODUCTION}

Groundwater is widely used as a source of water for various purposes. Contamination of groundwater has become a major problem in recent 
years, because many people depend on it. Once an aquifer is contaminated, it is extremely difficult to clean it up and restore the quality of its water. The chemical composition of groundwater depends on many processes, which include atmospheric input, interaction of water with soil and rocks, input of chemicals derived from human activities etc. Groundwater may not meet the appointed standards because it contains dissolved constituents of natural or human origin and/or pathogens. In a rural area, there are many possible sources for groundwater contamination: leakage from landfills, from agricultural activities, etc. Nitrogen compounds are generally very mobile in the environment participating in many biological and physiochemical processes. The main processes concerning soil, groundwater and plants are presented in figure 1 (Bovis, 1987).

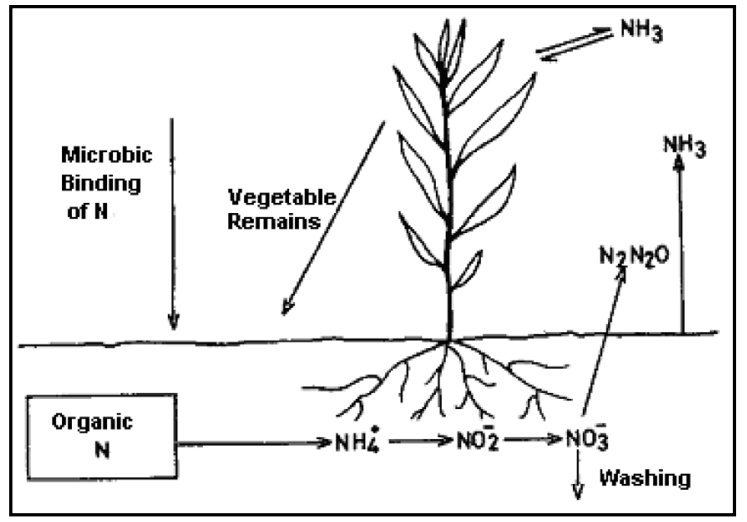

Figure 1: Chemical behaviour of $\mathrm{N}$ in planted soil

Contamination of groundwater with nitrate is a global problem (Spalding and Exner, 1993). It may represent a loss of fertility from overlying soil, may cause the development of eutrophication phenomena when the groundwater discharges into surface water and can potentially cause health problems (McLay et al., 2001) to large numbers of people (in cities and rural areas) relying on groundwater for drinking water (Thornburn et al., 2003)

Nitrate is a major water pollutant. It is toxic to humans and animals because, in their digestive system it is reduced to nitrite that binds with hemoglobin in the blood to restrict the transfer of oxygen from the lungs. This is termed methemoglobinemia (Ward and Elliot, 1995). Several anthropogenic activities can raise nitrate levels in groundwater with most important the increased use of inorganic fertilizers (EEA, 1999). Nitrate can be introduced into surface and groundwater via runoff and infiltration.

\section{DESCRIPTION OF THE STUDY AREA}

Thessaly is located in the central part of Greece (Fig. 2) (website 2) and is one of the most productive agricultural areas of the country. The area depends heavily on groundwater for both irrigation and human consumption. At the plain of Thessaly are cultivated many kinds of crops, such as cotton, corn, sugar beet, tomato and cerealscrops. Most farmers prefer to cultivate cottoncrops or sugar-beet-crops due to their high profit, although, these crops require increased water quantities for their proper irrigation. Table 1 shows that in the last twenty years the irrigated land in Thessaly has increased (Website 1) and the increasing trend is still continuing.

Table 1. Irrigated land in Thessaly

\begin{tabular}{lc}
\hline Year & Irrigated Land (ha) \\
\hline 1977 & 105,000 \\
1983 & 150,000 \\
1991 & 167,200 \\
1994 & 242,447 \\
\hline
\end{tabular}

A large project for the diversion of about one third of the water of Acheloos River, a major river of western Greece to Pinios River at Thessaly has been planned for hydroelectric energy production and irrigation purposes. The project is under development although there is a significant debate between Greek Government and Environmental non Governmental Organisations (NGO's) about the environmental impacts of the diversion on the hydrology of the catchment area of the Acheloos and the riverine and estuarine ecosystems (Greek NGO's, 1993; Greek Ministry for the Environment, 1989).

The main part of this study took place at the region of Farsala, which is located in southwestern Thessaly (Fig. 3). This region covers an area of $740 \mathrm{~km}^{2}$ and the population is about 22,000. The crop-area is about $478 \mathrm{~km}^{2}$. Enipeas River and its branches flowing in the central area of Farsala, constitute a fertile plain. The city of Farsala represents an economical, commercial and agricultural center, while its inhabitants are occupied in farming, stockbreeding and at local small industries.

Once, the level of water table in the plain that is studied was very near the surface (at depth 2 - 5 $\mathrm{m})$. However, the last few years the level has fallen in depth $10-15 \mathrm{~m}$ or more (Mariolakos et al., 2001), as a result of overpumping. There are not 
significant point sources of pollution in the area, beyond the intensive agriculture that is a diffused one. The cities and the villages can be considered as scattered pollution sources as in each house there is an unsealed septic tank.

The movement of groundwater in the region of Farsala shows that groundwater is headed northwestwards (Mariolakos et al., 2001).

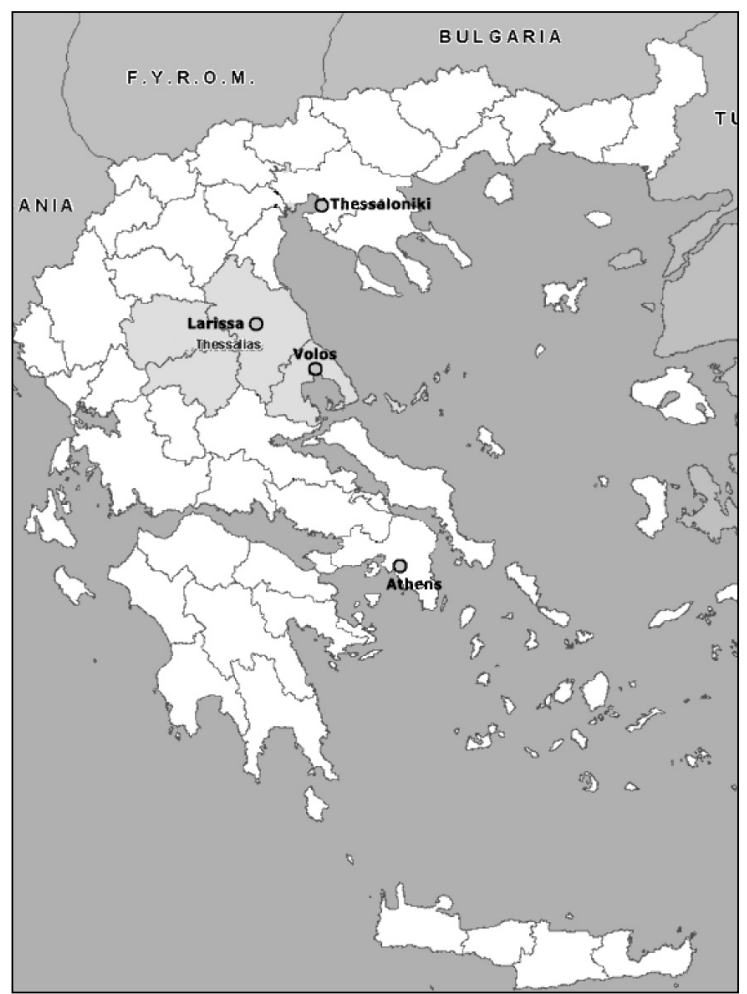

Figure 2: Thessaly

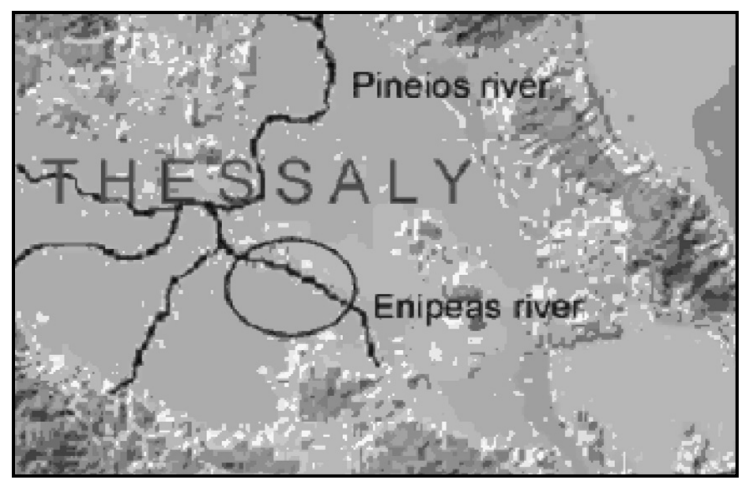

Figure 3: The region of Farsala

\section{SAMPLING AND METHODOLOGY}

Under a preliminary study at southern Thessaly nitrate concentrations were measured during May and August of 2001 in an extended area that is shown in figure 4 and can be separated in four fields.

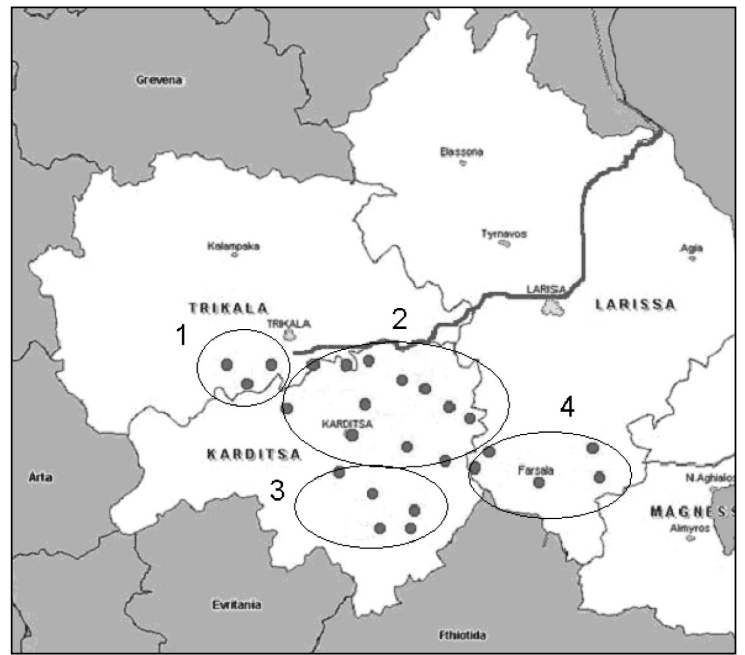

Figure 4: The sampling area of the preliminary study

The results from the preliminary study, as showed in Figure 5, indicate that field 4 was the most affected by nitrate pollution. Thereby, a detailed main study followed in this field which is the region of Farsala.

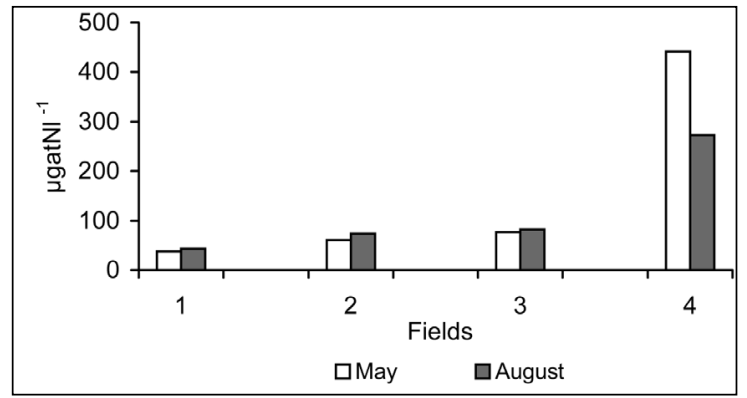

Figure 5: Average nitrate values at the preliminary study

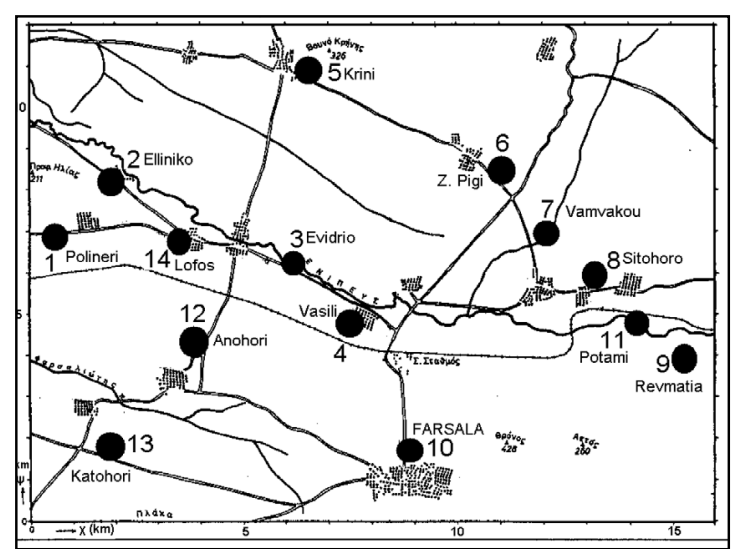

Figure 6: The sampling area of the main study 
This study included two samplings during May and August of 2002. In May the water table is at high level due to the winter and early spring rainfalls, while at the end of the summer the level of the water table is as low as it can be due to the use of very large amounts of water for irrigation.

Fourteen sampling stations were selected and the samples were received from deep $(80-100 \mathrm{~m})$ wells. The sampling stations are shown in Figure 6. The samples were filtered through $0.45 \mu \mathrm{m}$ Millipore filters and were preserved at $-4{ }^{\circ} \mathrm{C}$. In every sampling period, $\mathrm{pH}$, conductivity and temperature were measured in situ by portable equipment. Nitrite, phosphate and ammonia were measured by standard spectrometry methods using a Cary 1E Double-Beam Spectrophotometer. Nitrate concentrations were measured with an Auto Analyzer II Bran+Lubbe. Heavy metals were measured by a Varian 640-Z Graphite Furnace A.A.S. (Atomic Absorption Spectrophotometer) with background correction based on Zeeman Effect, whereas $\mathrm{Ca}, \mathrm{Na}, \mathrm{K}, \mathrm{Mg}$ were determined by a Varian SpectrAA-200 Emission A.A.S. (Grasshoff et al., 1999).

\section{RESULTS AND DISCUSSION}

The Pipper's diagram (Drever, 1982) that is presented in Figure 7 (for the August sampling) indicates that the groundwater of the area belongs to the $\mathrm{Ca}-\mathrm{HCO}_{3}^{-}$-type. The same diagram was received for the period of May.

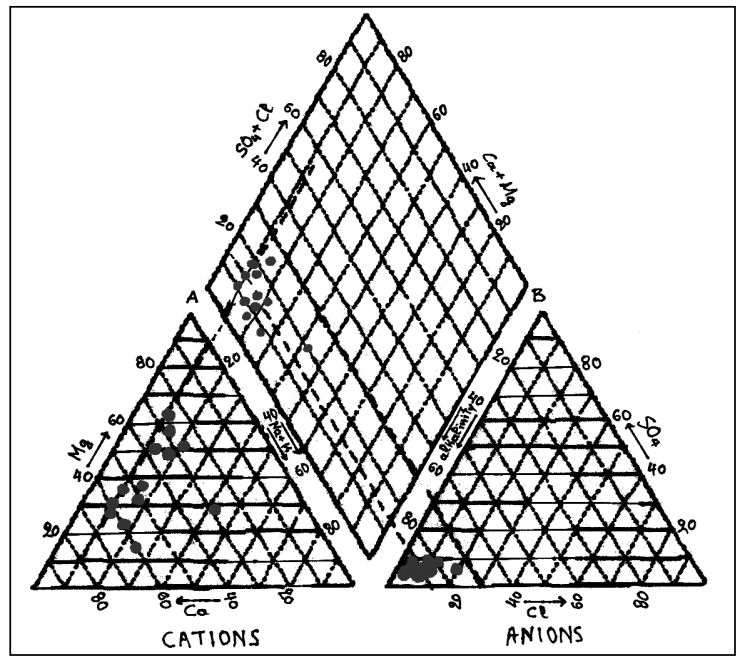

Figure 7: Pipper's Diagram

The correlations between various main water constituents are very interesting as they characterize the hydrogeochemical state of the sampling area (Kallergis, 1986; Lamprakis, 1994).

The ratio $\mathrm{Mg} / \mathrm{Ca}$ in the sampling area ranged between 0.2 and 0.6 indicating groundwater originating from calcareous aquifer and between 2 and 4 indicating origin from siliceous aquifer.

The ratio $(\mathrm{Ca}+\mathrm{Mg}) /(\mathrm{K}+\mathrm{Na})$ varied mainly from 1 to 6 indicating that there are aquifers with continuous flow. The ratio increased to 10-11 near calcareous aquifer (higher flow is expected there), while in the central plains has smaller values (3 - 4). High percentage of samples was found with ratio $\mathrm{Na} / \mathrm{K}$ among $12-30$. These values indicate a constant flow in the sampling area. In certain central samples the ratio values were 50-70 indicating the existence of 'old' water. In few samples the ratio was lower than 10 indicating meteoric water, i.e. rainwater.

The classification of irrigated water according to its conductivity, chloride concentration and degree of alkalinity is presented in table 2 (U.S.A., Department of Agriculture 1954).

$B A_{(N A)}=\frac{\mathrm{N} a^{+} \times 100}{C a^{+2}+M g^{+2}+N a^{+}}$

1. Excellent: Exceptional irrigation quality for all the plants, all the types of soils and with whatever system of irrigation.

2. Good: Good irrigation quality for almost all the plants and for soil with condition of good leaching and salt washing.

3. Permissible: It can be used for irrigation of plants with resistance in salts at permeable soil with condition of good leaching and salt washing.

4. Doubtful: It can be used for irrigation of plant with resistance in salts at permeable soil with conditions of good leaching and salt washing, provided with sufficient quantities activated calcium and organic matter.

5. Inappropriate: Inappropriate for irrigation. It will alkalize soil. This event will accelerate, if the soil does not have good conditions of leaching and salt washing and sufficient quantities of activate calcium and organic matter.

The waters of categories 3 (permissible) and 4 (doubtful) can be used for irrigation after expert advice from qualified services of the Ministry of Agriculture, depending on the resistance of crops 
Table 2. The classification of water for irrigation

\begin{tabular}{llll}
\hline Type & $\begin{array}{l}\text { Conductivity } \\
\left(\boldsymbol{\mu m h o s} \mathbf{~ c m}^{-\mathbf{1}}\right)\end{array}$ & $\begin{array}{l}\text { Chloride }(\mathbf{C l}) \\
\left(\mathbf{m e q} \mathbf{l}^{-\mathbf{1}}\right)\end{array}$ & $\begin{array}{c}\text { Degree of alkalinity } \\
\left(\mathbf{B A}_{(\mathbf{N a})}\right)\end{array}$ \\
\hline Excellent & $<250$ & $<1$ & $<20$ \\
Good & $250-750$ & $1-3$ & $20-40$ \\
Permissible & $750-1500$ & $3-8$ & $40-60$ \\
Doubtful & $1500-3000$ & $8-15$ & $60-70$ \\
Inappropriate & $>3000$ & $>15$ & $>70$ \\
\hline
\end{tabular}

in salts, the characteristics of soil, the conditions of leaching and washing, the level of groundwater table, the particular sensitivity of plants at the ions of water, the irrigation's system and the climatic conditions of the area.

During May the water of 7 sampling stations (50 $\%)$ were characterized as 'good', the water of one station was characterized 'doubtful', whereas the water of the rest 6 sampling stations (43\%) was characterized as 'permissible'. For the period of August, water 'good' for irrigation was found in 43 $\%$ of the sampling stations (6) while the water of 57 $\%$ of the sampling stations (8) was characterized permissible (Fig.8, 9).

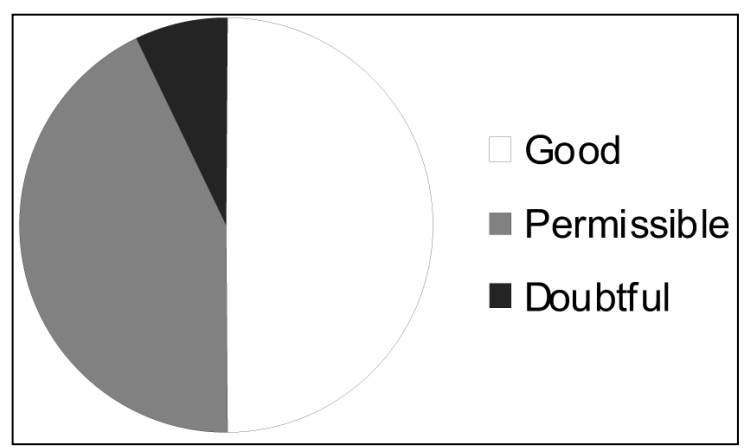

Figure 8: The classification of water for irrigation in May

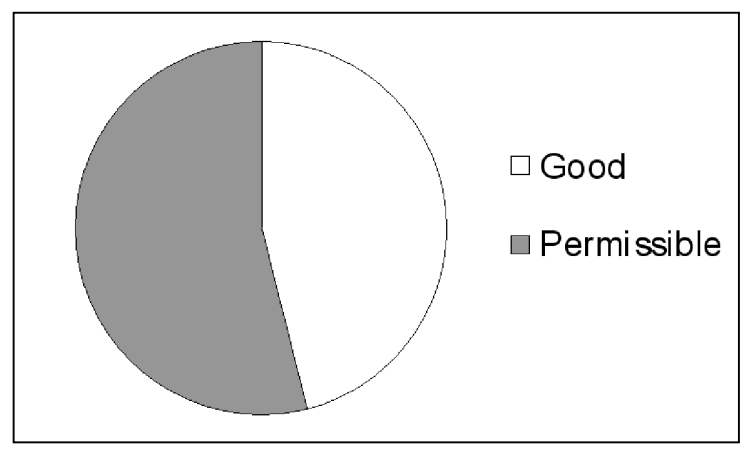

Figure 9: The classification of water for irrigation in August
The nitrate concentrations were very high (average values $435 \mu$ gat $~^{-1}$ for May and $734 \mu$ gat $~^{-1}$ for August). Figure 10 indicates that nitrate pollution is a significant problem because the concentrations were very high in August. In particular the nitrate values exceeded the Maximum Admissible Concentration for human consumption $(\mathrm{MAC}=$ $800 \mu$ gat N 1 $^{-1}$ ) at about $40 \%$ of the samples, thus the water was improper. (Council Directive 80/778/EEC). Furthermore for the same sampling period nitrate values exceeded the Maximum Desirable Concentration $\left(\mathrm{MDC}=400 \mu \mathrm{gatN} \mathrm{^{-1 }}\right.$ ) at about $80 \%$ of the samples. The oxidation of nitrite and ammonia and the increased irrigation during summer has led to increased nitrate concentrations during August (Bovis, 1987)

The nitrite concentrations were also increased (average values $5.22 \mu$ gatN ${ }^{-1}$ and $0.37 \mu$ gatN ${ }^{-1}$ respectively for May and August). Contrary to nitrate, the nitrite concentrations were increased during May, when some high values exceeded the Maximum Admissible Concentration for human consumption $\left(\mathrm{MAC}=2.20 \mu \operatorname{gatN~}^{-1}\right)$ (Fig. 11).

The variations of ammonia concentrations generally followed the ones of nitrite (Fig. 12). The average value in May was $0.52 \mu$ gatN $~^{-1}$ and in August $0.23 \mu$ gat $~^{-1}$. Both ammonia and nitrite levels were increased in May probably due to fertilizer application in this period. Only one value exceeded the Maximum Admissible Concentration for human consumption of $29.4 \mu \mathrm{gatN} \mathbf{1}^{-1}$. The significant reduction of nitrite and ammonia during August is probably due to oxidation to nitrate (Bovis, 1987).

The phosphate concentrations (average values 0.73 $\mu$ gat $\mathrm{l}^{-1}$ and $0.32 \mu$ gat $\mathrm{l}^{-1}$ ) were generally low and below the Maximum Admissible Concentration $\left(\mathrm{MAC}=535 \mu\right.$ gat l$\left.^{-1}\right)$

The concentrations of heavy metals were also very low. The average values for cadmium, lead, copper and zinc were $0.011 \mu \mathrm{g} \mathrm{l}^{-1}, 0.65 \mu \mathrm{g} \mathrm{l}^{-1}, 4.90 \mu \mathrm{g} \mathrm{l}^{-1}$ and $0.091 \mathrm{mg} \mathrm{l}^{-1}$ respectively in May and $0.040 \mu \mathrm{g} \mathrm{l}^{-1}$, 
$0.13 \mu \mathrm{g} \mathrm{l}^{-1}, 1.51 \mu \mathrm{g} \mathrm{l} \mathrm{l}^{-1}$ and $0.053 \mathrm{mg} \mathrm{l}^{-1}$ respectively in August. A decreasing trend was observed between the two sampling periods.

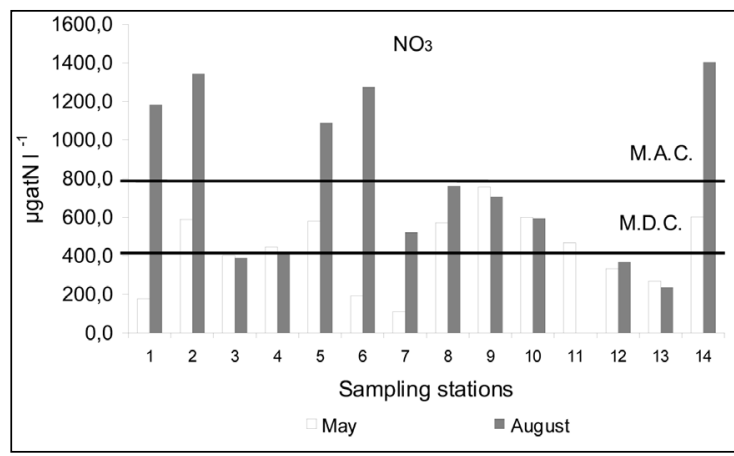

Figure 10: Nitrate concentrations in all sampling stations

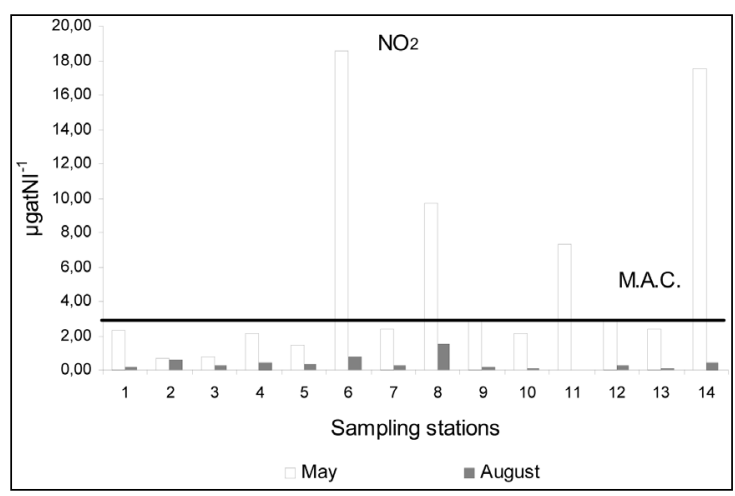

Figure 11: Nitrite concentrations in all sampling stations

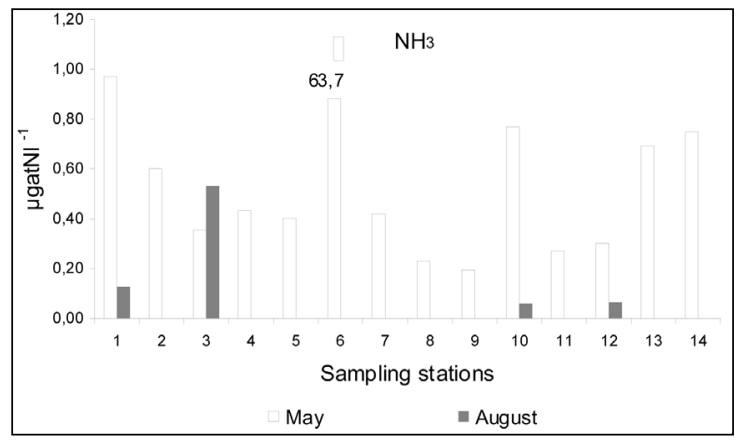

Figure 12: Ammonia concentrations in all sampling stations

Two similar studies have been carried out in Thessaly during 1995 and 2000 (Akrivos et al., 1996; Kariotis 2001). The average values for the common sampling sites and for the periods of August 1995 and 2000 respectively are presented in Figure 13. The average nitrate concentration of the present study is sufficiently higher from the one of 1995.On the other hand, the average concentration of nitrates of the present study and the one of 2000 are quite similar with a small reduction in the present one. This reduction is probably due to a different way of fertilization, as in the last years there has been an effort for controlled fertilization.

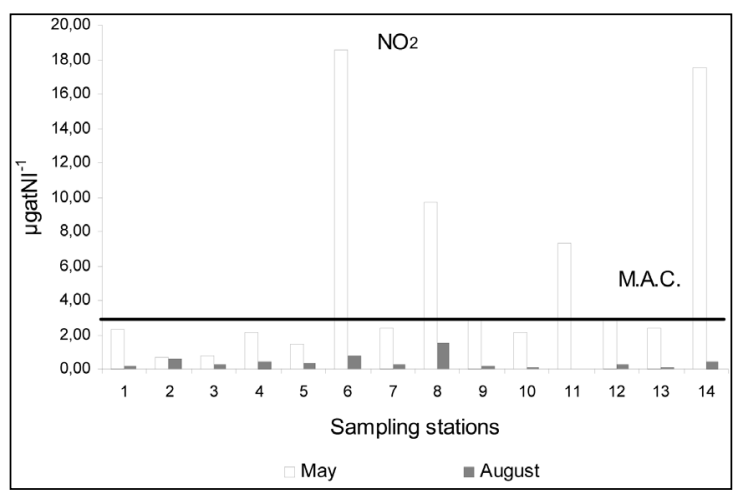

Figure 13: A comparison of three studies

\section{CONCLUSIONS}

The main conclusions that can be drawn from this study are:

- The groundwater of the study area belongs to the $\mathrm{Ca}-\mathrm{HCO}_{3}^{-}$type.

- The ionic ratios $(\mathrm{Ca}+\mathrm{Mg}) /(\mathrm{Na}+\mathrm{K})$ and $\mathrm{Na} / \mathrm{K}$ show that there is constant flow and the ratio $\mathrm{Ca} / \mathrm{Mg}$ shows that the groundwater originates mostly from calcareous aquifers and less from siliceous aquifers.

- The classification according to conductivity, chloride concentration and degree of alkalinity characterizes the groundwater as water of medium quality that can be used for irrigation at soils with good conditions of leaching.

- The water in a high percentage of wells (about $40 \%$ ) during August is characterized improper for human consumption because of the high nitrate content. This result reveals that there is a significant problem of nitrate pollution in the study area.

- The nitrite and ammonia concentrations were also increased especially during May, probably, due to fertilizer application.

- The concentrations of heavy metals are generally low and they are not at present significant environmental problem. 


\section{REFERENCES}

Akrivos P., Kaklis T., Banakas K., Athanasias S., Soulios G., (1996), Chemical characteristics of groundwater at the northern plain area of Farsala, in Proceedings 2nd Greek Conference of Geology, Larissa, 430-432.

Bovis K.P. (1987), Fertility of Soil. Fertilizers - Fertilization, Agricultural University of Athens, 128, 132. Council Directive 80/778/EEC of 15 July 1980 relating to the quality of water intended for human consumption. European Community Environment Legislation, 7, Water, 17

Drever, J.I. (1982), The Geochemistry of Natural Waters: Surface and Groundwater Environments, 3rd ed., Upper Saddle River, NJ: Prentice Hall, 1, 410-411.

EEA. (1999), Groundwater quality and quantity in Europe. Environmental assessment report no 3, Copenhagen: European Environmental Agency

Grasshoff K, Kremling M., Ehrhardt M. (1999), Methods of Seawater Analysis, 3rd ed., WILEY-VCH, ch. 10,162 , ch. 11, 230, ch. 12, 263-271.

Greek N.G.O's (WWF-Greece, Hellenic Society for the Preservation of Nature, Hellenic Society for the Protection of the Environment and the Cultural Herritage, Greek Ornithological Society), (1993), The divertion of Acheloos: a critical view on the environmental and economical impacts. Report to DG XI, E.U., Brussels.

Kallergis G. (1986), Applied Hydrogeology, T.C.G. Publ., Athens, A,1-88

Kariotis Th., (2001), Monitoring net of the underground aquifers of Thessaly.

Labrakis, N. (1994), Introduction in Hydrogeology, University of Patra Publ., 158.

Mariolakos H., Lekkas S., Alexopoulos A., Fountoulis I., Spiridonos E., Mpantekas I, Mariolakos D., Andreadakis E. (2001), Technical enrichment of underground karstic aquifer of Mt. Filliou in the area of Farsala (Thessalia). J. Greek Geological Society, Proceedings, 9th International Conference of Geology, Athens, XXXXIV/5, 1843-1850.

Mariolakos H., Lekkas S., Papadopoulos T., Alexopoulos A., Fountoulis I., Alexopoulos I., Spiridonos E., Mpantekas I, Mariolakos D., Andreadakis E. (2001), Underground tectonic structure in the basin of Farsala (Thessalia) as a determinant configuration of the hydrogeological conditions of the area. J. Greek Geological Society, Proceedings, 9th International Conference of Geology, Athens, XXXXIV/5, 1851-1858.

McLay, C.D.A, Dragten, R., Sparling, G., Selvarajah, N. (2001), Predicting groundwater nitrate concentrations in a region of mixed agricultural land use: a comparison of three approaches, Environmental Pollution, 115, 191.

Spalding, R.F., Exner, M.E. (1993), Occurrence of nitrate in groundwater - a review. Journal of Environmental Quality, 22, 392 - 402.

The Greek Ministry for the Environment, (1989), Study of environmental impacts at the Acheloos estuary, from the divertion of the river to Thessaly, Athens.

Thornburn P.J., Biggs J.S., Weier K.L., Keating B.A. (2003), Nitrate in groundwaters of intensive areas in coastal Northeastern Australia, Agriculture, Ecosystems and Environment, 94, 49.

United States Department of Agriculture, (1954), Diagnosis and improvement of saline and alkali soils, Editor : L.A. Richards, Agriculture Handbook No 60.

Ward, A.D., Elliot, W.J. (1995), Environmental Hydrology, Lewis Publishers, Boca Radittaton, Florida, ch. 10, 328 .

Web sites

http://www.agrinio.net/perivallon/grax202.html (2002)

http://www.geocities.com/world_greek_geografia/Greece/Greecepref/Thessalia.html (2002) 
